Proc. Indian Acad. Sci. (Earth Planet. Sci.), Vol. 99, No. 1, March 1990, pp. 21-37.

(C) Printed in India.

\title{
Patent mantle-metasomatism: Inferences based on experimental studies
}

\author{
Y THIBAULT and A D EDGAR \\ Department of Geology, University of Western Ontario, London, Canada N6A 5B7
}

\begin{abstract}
K}, \mathrm{Na}$ and $\mathrm{Ca}$ are the most common elements transported during mantle metasomatism and result in formation of phlogopite (K), amphibole (Na) and clinopyroxene (Ca) by various reactions. This review presents models for this type of metasomatism based on experiments on the pyrolite- $\mathrm{K}_{2} \mathrm{CO}_{3}-\mathrm{H}_{2} \mathrm{O}$, pyrolite- $\mathrm{Na}_{2} \mathrm{CO}_{3}-\mathrm{H}_{2} \mathrm{O}$ systems and on the pyrolite- $\mathrm{CaCO}_{3}$ system. The addition of $\mathrm{K}_{2} \mathrm{CO}_{3}$ and $\mathrm{Na}_{2} \mathrm{CO}_{3}$ lowers the liquidus of pyrolite providing a low temperature, alkali-rich hydrous melt which may ascend and metasomatize overlying mantle regions. Several reactions are proposed for the formation of phlogopite and amphibole (pargasite-edenite) in these systems. The compositions of amphiboles correspond to those found in metasomatized mantle xenoliths. In contrast, Ca-metasomatism is considered to be mainly an anhydrous process in which orthopyroxene and carbonate react to produce clinopyroxene, olivine and $\mathrm{CO}_{2}$. High pressure liquids in this model system are of carbonatitic composition and this low viscosity melt can ascend converting harzburgite mantle assemblages to olivine-rich wehrlite.

Based on an inverse experimental approach, moderately high degrees of partial melting of a model metasomatized alkali clinopyroxenite xenolith yield liquids at $30 \mathrm{~kb}$ which are very comparable in composition to the lavas enclosing such types of xenoliths.

Experimental modelling of mantle metasomatism produces assemblages which are in good agreement with the mineral assemblages and textural relationships found in metasomatized mantle xenoliths from areas such as West Eifel and South-West Uganda.
\end{abstract}

Keywords. Mantle metasomatism; pyrolite systems; phlogopite; amphibole; clinopyroxene; xenolith.

\section{Introduction}

The idea of mantle metasomatism is relatively recent. Harte and Gurney (1975) discussed changes in upper mantle-derived xenoliths in some South African kimberlites. Lloyd and Bailey (1975) suggested that the absence of garnet and orthopyroxene in alkali clinopyroxenite xenoliths in the ultrapotassic provinces of South-West Uganda and Eifel, West Germany was caused by alteration resulting from metasomatic fluids. The concept of mantle metasomatism is being widely accepted as one of the causes of mantle heterogeneity (c.f. Bailey 1982, 1987; Menzies and Hawkesworth 1987).

Dawson (1984) subdivided metasomatic processes into patent and cryptic types. Experimental modelling can only deal with patent metasomatism in which new mineral assemblages can be readily recognized petrographically.

The concept of mantle metasomatism is important with respect to the source regions for kimberlites and other alkaline mafic-ultramafic magmas. Variation in the chemistry of melts may be associated with the processes of rifting or it may be the result of mantle heterogeneities caused by metasomatism. The nature of the metasomatic fluid is a subject of debate, but melts seem to be the most likely media. 
Bailey (1987) considered metasomatism to occur by fluids under subsolidus conditions. Spera (1987) suggested that during cooling the metasomatizing agent may evolve from a volatile-saturated melt to a solute-saturated supercritical fluid.

Bailey (1987) subdivides the characteristic lithophile-element-bearing minerals found as a result of metasomatism of peridotitic mantle assemblages into major minerals, which include phlogopite, amphibole, clinopyroxene, and carbonates; and minor minerals comprising phosphates, titanates, oxides and sulphides. The elements introduced by the metasomatic fluids include $\mathrm{H}, \mathrm{C}, \mathrm{F}, \mathrm{Ne}, \mathrm{Al}, \mathrm{P}, \mathrm{S}, \mathrm{Cl}, \mathrm{K}, \mathrm{Ca}, \mathrm{Ti}, \mathrm{Fe}$, $\mathrm{Rb}, \mathrm{Y}, \mathrm{Zr}, \mathrm{Nb}, \mathrm{Ba}$ and the rare earths (Bailey 1982). This metasomatic material is usually introduced along grain boundaries and veins and hence evidence of the amount and the types of elements removed are not apparent.

Experiments designed to model mantle metasomatism are much simpler than the natural process. Two approaches have been pursued-determination of the solubility of major and trace elements by metasomatic fluids (note particularly the review by Eggler 1987); and experiments designed to determine the conditions and concentrations under which characteristic metasomatic minerals such as phlogopite, clinopyroxene and amphibole form. The latter experiments have not been as detailed as those designed to determine the solubility of elements in metasomatic fluids, done principally by D H Eggler and co-workers. Experiments to model the conditions of formation of characteristic metasomatic minerals include investigations of the pyrolite $-\mathrm{K}_{2} \mathrm{CO}_{3}-\mathrm{H}_{2} \mathrm{O}$ system at 20 and $30 \mathrm{~kb}, 850-950^{\circ} \mathrm{C}$ by Edgar and Arima (1984), and similar experiments at $20 \mathrm{~kb}$, in the pyrolite- $\mathrm{Na}_{2} \mathrm{CO}_{3}-\mathrm{H}_{2} \mathrm{O}$ system described by $\mathrm{McNeil}$ and Edgar (1987). More recently, we have carried out experiments in the pyrolite- $\mathrm{CaCO}_{3}$ system between 20 and $30 \mathrm{~kb}$ at $900-1300^{\circ} \mathrm{C}$. An experimental study on the nature of carbonatitic melts in the system (pyrolite- $40 \%$ olivine) $-\mathrm{H}_{2} \mathrm{O}-\mathrm{CO}_{2}$ and on the potential role of these melts in metasomatic processes has been undertaken by Wallace and Green (1988) and Green and Wallace (1988). An inverse approach to these experiments in which the compositions of liquids (as glass) from partial melting of a model-metasomatized mantle source are compared with the natural lavas believed to be derived from such a source was undertaken by Lloyd et al (1985).

\section{Experimental techniques}

All experiments were done in a $1.27 \mathrm{~cm}$ piston-cylinder apparatus (Boyd and England 1960) using a "hot-piston out" technique in which the starting material together with the requisite amounts of $\mathrm{H}_{2} \mathrm{O}$ were sealed in $\mathrm{Pt}, \mathrm{Ag}_{75} \mathrm{Pd}_{25}$ or $\mathrm{Ag}_{50} \mathrm{Pd}_{50}$ capsules. The choice of capsule material was dictated by the temperature used, with $\mathrm{Pt}$ capsules being required above $1250^{\circ} \mathrm{C}$. The well-known loss of iron by alloying with these capsule materials, particularly with $\mathrm{Pt}$, is not significant in the experiments of Edgar and Arima (1984) or McNeil and Edgar (1987) which were done at relatively low temperatures but is more important in the experiments described by Lloyd et al (1985) and those for the pyrolite- $\mathrm{CaCO}_{3}$ system described in this paper. Temperatu in in this type of experiment were $\pm 5^{\circ} \mathrm{C}$ and pressures to within $\pm 5 \%$ of stated values. No frictional correction was made in the measurement of pressure. The e.m.f. variation related to pressure during temperature measurements with $\mathbf{P t}-\mathbf{P t}_{\mathbf{9 0}} \mathbf{R h}_{10}$ thermocouples was also not taken into account. 
Establishment of equilibrium, normally examined by reversing the experiment over a phase boundary, is difficult for subsolidus experiments in which there is a fluid of changing composition. McNeil and Edgar (1987) consider that the consistency of proportions of phases probably indicates equilibrium. Of equal importance is the establishment of the relative amounts and changes in composition of the new minerals or of the glass in experiments designed to model metasomatic processes. Edgar and Arima (1984) determined the relative (but not absolute) amounts of the "metasomatic" minerals by their X-ray diffraction intensities relative to the other phases. A more sophisticated method in which a weighed amount of an internal calcite standard is introduced, was used by $\mathrm{McNeil}$ and Edgar (1987) to assess relative proportions of 'metasomatic' minerals. In the experiments of Lloyd et al (1985) the proportions of glass representing the degree of partial melting of the model-metasomatized mantle source were established optically by point-counting each run, and by a least squares calculation based on the compositions of the run products as determined by electron microprobe. A least-squares method was also used in the pyrolite- $\mathrm{CaCO}_{3}$ system described below.

The compositions of the phases in these experiments were determined by electron microprobe except for those found in Edgar and Arima's (1984) study in which they were too fine-grained. Distinction between 'primary' (equilibrium) and 'quench' (nonequilibrium) minerals was based on their textural and compositional relationships.

\section{Results and implications}

\subsection{The pyrolite- $\mathrm{K}_{2} \mathrm{CO}_{3}-\mathrm{H}_{2} \mathrm{O}$ system}

This study was originally designed to model K-metasomatism of the pyrolite model mantle composition at P-T conditions $\left(20-30 \mathrm{~kb}, 850-950^{\circ} \mathrm{C}\right)$ near that of the continental geotherm. Thus the reactions primarily represent subsolidus ones.

Figure 1 shows that at $30 \mathrm{~kb}, 850$ and $950^{\circ} \mathrm{C}$ the amount of phlogopite relative to olivine, orthopyroxene and clinopyroxene systematically increases with concentration of $\mathrm{K}_{2} \mathrm{O}$ in solution up to about $3.5 \mathrm{~g} \mathrm{~K}_{2} \mathrm{O} / 10 \mathrm{~g}$ solution, and decreases at higher concentrations in which a melt forms. Such a low temperature melt may form by the decomposition of phlogopite to olivine + liquid or more probably represents the beginning of melting of a highly $\mathrm{K}$-enriched pyrolite. The latter conclusion is supported by the experiments of Takahashi and Kushiro (1983) on the melting of a $\mathrm{K}$-enriched peridotite which lowered solidus temperatures by $70^{\circ}$ and $150^{\circ} \mathrm{C}$ at 20 and $30 \mathrm{~kb}$ respectively. The importance of Edgar and Arima's (1984) experiments is that they show that phlogopite is the only characteristic phase resulting from this type of subsolidus $\mathrm{K}$-metasomatism at $30 \mathrm{~kb}$ and that the olivine/clinopyroxene and olivine/orthopyroxene ratios decrease (figure 1). The Al for the formation of phlogopite is obtained from decreasing stability of garnet as phlogopite increases. Edgar and Arima (1984) propose the reaction:

$$
\begin{aligned}
& 5 \text { olivine }+ \text { orthopyroxene }+ \text { garnet } \stackrel{\mathrm{K}_{2} \mathrm{O}+\mathrm{H}_{2} \mathrm{O}}{\longrightarrow} \\
& \text { phlogopite }+(5-x) \text { olivine }+(1+y) \text { orthopyroxene. }
\end{aligned}
$$

Results of this system at $20 \mathrm{~kb}$ (figure 2a) show a similar trend of increasing phlogopite relative to olivine and pyroxenes with increasing $\mathrm{K}_{2} \mathrm{O}$ concentration in 


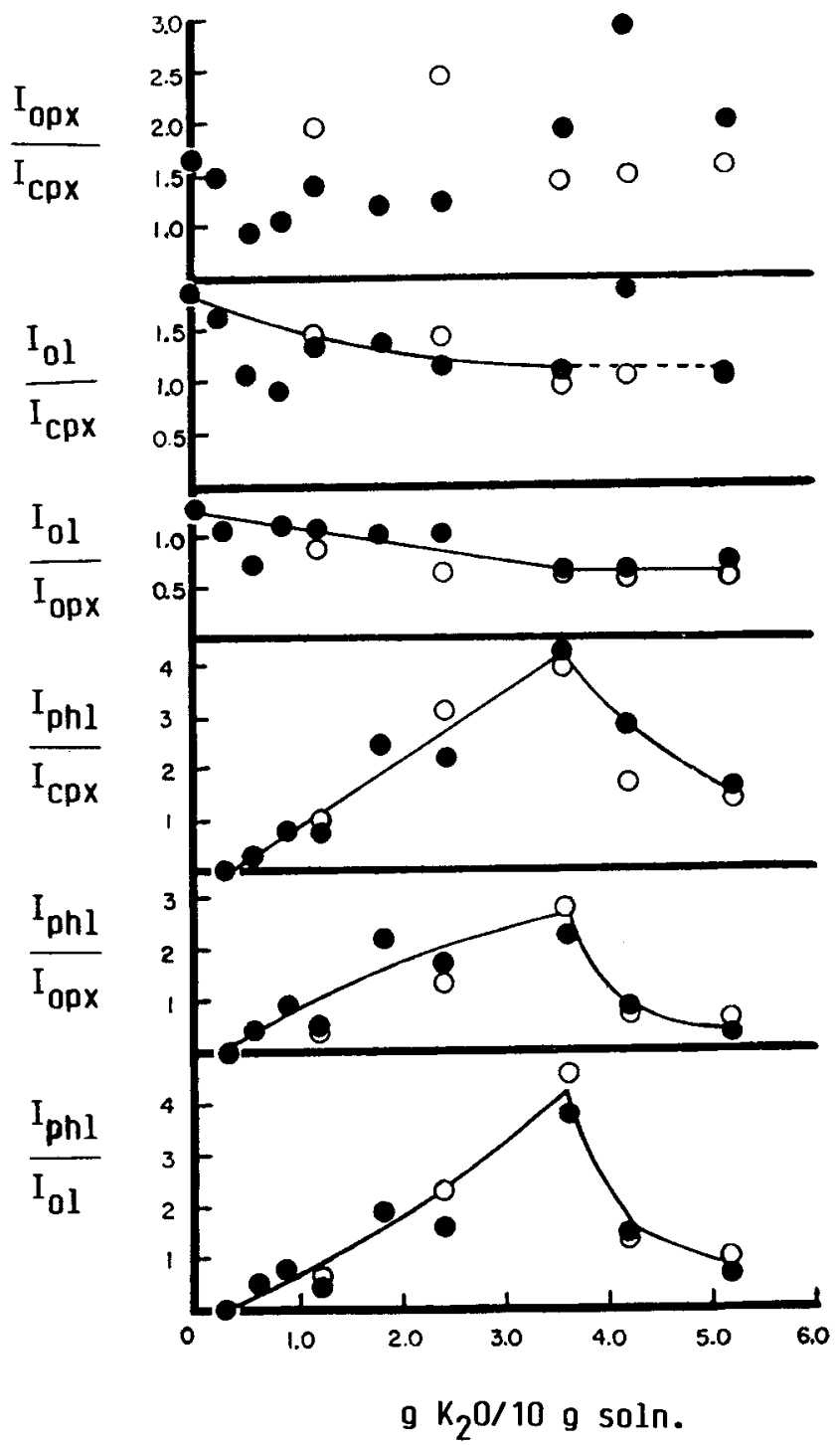

Figure 1. Ratios of $\mathrm{X}$-ray diffraction intensities of phlogopite (phl) relative to clinopyroxene (cpx), orthopyroxene (opx) and olivine (ol); of ol relative to opx and cpx; and of opx relative to $\mathrm{cpx}$ with increasing concentration of $\mathrm{g} \mathrm{K}_{2} \mathrm{O} / 10 \mathrm{~g}$ solution in the system pyrolite- $\mathrm{K}_{2} \mathrm{CO}_{3}$ $\mathrm{H}_{2} \mathrm{O}$ at $30 \mathrm{~kb}$ and $950^{\circ} \mathrm{C}$ (solid circles) and $850^{\circ} \mathrm{C}$ (open circles) (after Edgar and Arima 1984).

solution, but at this lower pressure no melt occurs even at extreme concentrations of $\mathrm{K}_{2} \mathrm{O}$. Amphibole occurs in the $20 \mathrm{~kb}$ runs. This mineral progressively decreases relative to olivine, orthopyroxene and clinopyroxene with increasing $\mathrm{K}_{2} \mathrm{O}$ in solution and is not present at greater than $1.8 \mathrm{~g} \mathrm{~K}_{2} \mathrm{O} / 10 \mathrm{~g}$ solution (figure 2a). The composition of this amphibole is likely to be pargasitic in composition.

Figure $2 b$ shows the relative variations of olivine to orthopyroxene and clinopyroxene and of orthopyroxene to clinopyroxene. In contrast to the $30 \mathrm{~kb}$ experiments (figure 1), there is a suggestion that the olivine/orthopyroxene ratio 


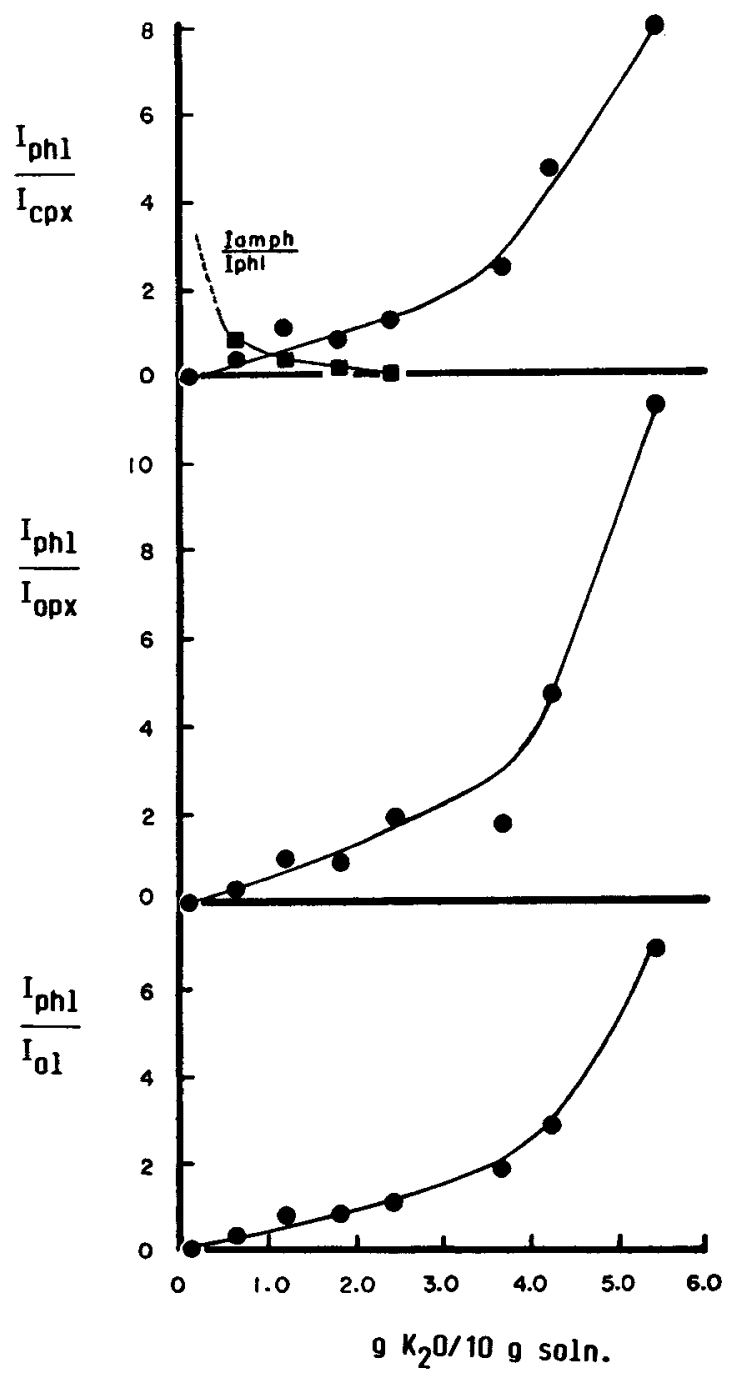

Figure 2a. Ratios of X-ray diffraction intensities of phlogopite relative to cpx, opx, ol and of amphibole (amph) to phl with increasing concentration of $\mathrm{g} \mathrm{K}_{2} \mathrm{O} / 10 \mathrm{~g}$ solution in the system pyrolite- $\mathrm{K}_{2} \mathrm{CO}_{3}-\mathrm{H}_{2} \mathrm{O}$ at $20 \mathrm{~kb}$ and $950^{\circ} \mathrm{C}$.

increases with increasing $\mathrm{K}_{2} \mathrm{O}$ in the system. The orthopyroxene/clinopyroxene in the $20 \mathrm{~kb}$ runs exhibits a systematic decrease with increasing $\mathrm{K}_{2} \mathrm{O}$ (figure $2 \mathrm{~b}$ ). As in the $30 \mathrm{~kb}$ experiments, the olivine/clinopyroxene ratio decreases with increasing $\mathrm{K}_{2} \mathrm{O}$.

Edgar and Arima (1984, pp. 530-534) suggest a number of hypothetical reactions at $20 \mathrm{~kb}$ to explain the early formation of amphibole and its disappearance with increasing concentration of $\mathrm{K}_{2} \mathrm{O}$, when phlogopite becomes the only diagnostic mineral (figure 2a). At low concentrations of $\mathrm{K}_{2} \mathrm{O}$ :

$$
\text { olivine }+ \text { orthopyroxene }+ \text { clinopyroxene }+ \text { amphibole }+ \text { spinel }
$$

with $\mathrm{K}_{2} \mathrm{O}$ in solution produces a rapid increase in phlogopite, along with increasing amounts of olivine and clinopyroxene and decreasing orthopyroxene as amphibole 


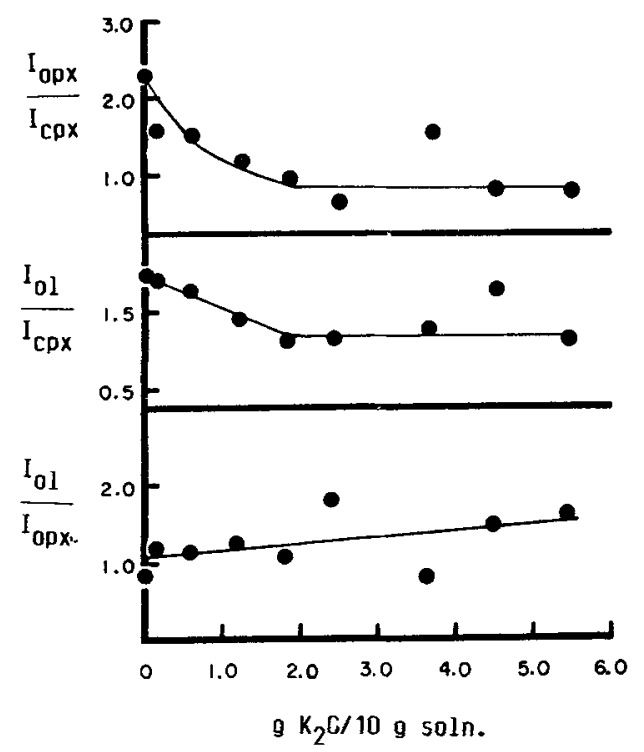

Figure 2b. Ratios of X-ray diffraction intensities of ol relative to cpx and opx and of opx relative to cpx with increasing concentration of $\mathrm{g} \mathrm{K}_{2} \mathrm{O} / 10 \mathrm{~g}$ solution for results shown in figure 2a (after Edgar and Arima 1984).

and spinel are consumed. With increasing concentrations of $\mathrm{K}_{2} \mathrm{O}$ the substantial increase in the amount of phlogopite relative to olivine and pyroxenes (figure $2 \mathrm{a}$ ) is produced by the reaction of $\mathrm{K}_{2} \mathrm{O}$ in solution with olivine, orthopyroxene and clinopyroxene. Al for the phlogopite is from residual spinel and from clinopyroxene which incorporates some of the Al from the amphibole present in the experiments at lower $\mathrm{K}_{2} \mathrm{O}$ concentrations.

The formation of very low temperature, $\mathrm{K}$-rich melts in these experiments at $30 \mathrm{~kb}$ indicates the potential of such melts to rise and induce K-metasomatism in nature at depths between 70 and $100 \mathrm{~km}(20$ to $30 \mathrm{~kb})$. These experiments also suggest that simple patent $\mathrm{K}$-rich metasomatism at these depths will rapidly result in the disappearance of garnet, and a decline in the amounts of spinel, amphibole and orthopyroxene.

The antipathetic relationship between amphibole and phlogopite in the $20 \mathrm{~kb}$ experiments, and the fact that the composition of this amphibole is not the typical K-richterite implies that the diagnostic K-rich metasomatic mineral at depths equivalent to $20 \mathrm{~kb}$ is also phlogopite.

\subsection{The pyrolite- $\mathrm{Na}_{2} \mathrm{CO}_{3}-\mathrm{H}_{2} \mathrm{O}$ system}

To model the effects of Na-metasomatism McNeil and Edgar (1987) studied the systems pyrolite- $\mathrm{Na}_{2} \mathrm{CO}_{3}-\mathrm{H}_{2} \mathrm{O}$ and pyrolite- $\mathrm{Na}_{2} \mathrm{CO}_{3}-\mathrm{K}_{2} \mathrm{CO}_{3}-\mathrm{H}_{2} \mathrm{O}$ in which the $\mathrm{K} /\left(\mathrm{K}+\mathrm{Na}\right.$ ) is fixed as 0.1 (molar) at $20 \mathrm{~kb}$ and $950^{\circ} \mathrm{C}$. The run products in this system were large enough for probe analysis and the relative proportions of different phases were determined by X-ray diffraction using an internal calcite standard.

Figure 3 shows that amphibole increases relative to calcite and olivine, and decreases relative to orthopyroxene for both experiments in which the concentration 


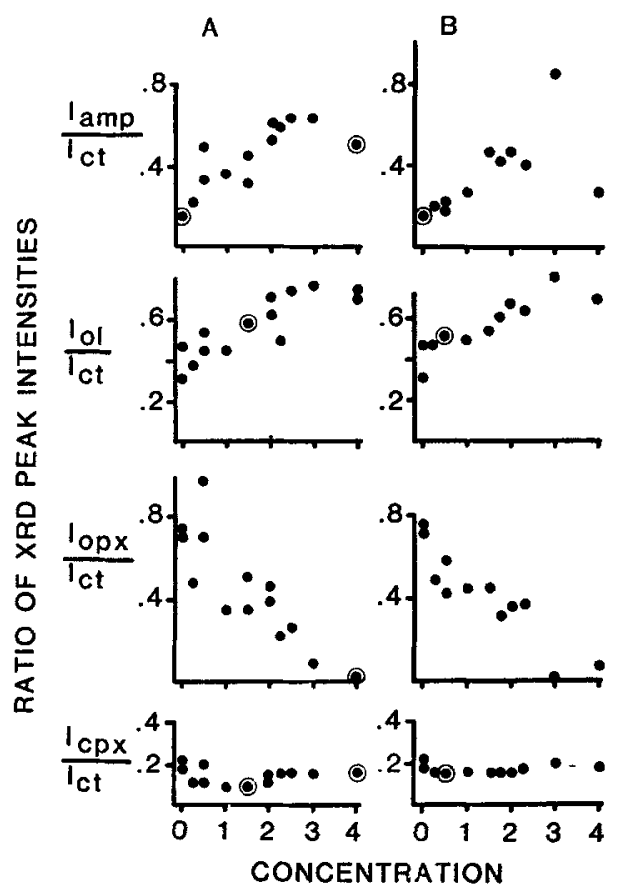

Figure 3. Ratios of $X$-ray diffraction intensities of amph, ol, opx, cpx relative to calcite (ct) standard with increasing concentrations of $\mathrm{g} \mathrm{Na}_{2} \mathrm{O} / 10 \mathrm{~g}$ solution (A) and $\mathrm{g} \mathrm{Na}_{2} \mathrm{O}+$ $\mathrm{K}_{2} \mathrm{O} / 10 \mathrm{~g}$ solution at a fixed molar $\mathrm{K} / \mathrm{K}+\mathrm{Na}=0.1$ (B) in the system pyrolite $(\mathrm{Na}, \mathrm{K})_{2} \mathrm{CO}_{3}-\mathrm{H}_{2} \mathrm{O}$ at $20 \mathrm{~kb}, 950^{\circ} \mathrm{C}$. Double circles represent two data points (after $\mathrm{McNeil}$ and Edgar 1987).

of $\mathrm{Na}_{2} \mathrm{O}$, as $\mathrm{g} \mathrm{Na}{ }_{2} \mathrm{O} / 10 \mathrm{~g}$ solution, and of $\mathrm{K}_{2} \mathrm{O}+\mathrm{Na}_{2} \mathrm{O}$, as $\mathrm{g}\left(\mathrm{K}_{2} \mathrm{O}+\mathrm{Na}_{2} \mathrm{O}\right) / 10 \mathrm{~g}$ solution, for a fixed molar $\mathrm{K} / \mathrm{K}+\mathrm{Na}$ ratio of 0.1 increased. The exact trend in clinopyroxene in these experiments is difficult to assess as there is an overlap between the main clinopyroxene and secondary olivine peaks on the X-ray diffractograms. Based on mass balance calculations McNeil and Edgar (1987) consider that clinopyroxene may be reduced to zero at high alkali fluid concentrations. Spinel and magnetite, present only in minor amounts, decrease with incre: ing concentrations of alkalies. At concentrations greater than about $3.0 \mathrm{~g}$ alkalis $/ 10 \mathrm{~g}$ solution for both the $\mathrm{Na}_{2} \mathrm{O}$ and $\mathrm{K}_{2} \mathrm{O}+\mathrm{Na}_{2} \mathrm{O}$ added experiments, the amounts of amphibole and olivine decrease (figure 3), and at these concentrations glass can be observed in the run products, suggesting that the solidus has been reached.

Based on microprobe analyses, McNeil and Edgar (1987) were able to suggest reactions responsible for the amphibole formation and to calculate likely compositions of the fluid phase in each run. Edenite to pargasite amphibole compositions show an increase in $\mathrm{Si}$ and $\mathrm{Na}$ and decrease in $\mathrm{Al}$ and $\mathrm{Ca}$ with increasing concentrations of alkalies (figure 4).

From the probe analysis of each mineral, X-ray intensity data and calculated mineral proportions based on least squares analysis, McNeil and Edgar (1987) were able to assume a fluid composition. With increasing concentration of $\mathrm{Na}$ (as $\mathrm{g} \mathrm{Na}_{2} \mathrm{O} / 10 \mathrm{~g}$ solution), the $\mathrm{Na}_{2} \mathrm{O}$ in the fluid increases from $1.13 \%$ at the lowest bulk $\mathrm{Na}_{2} \mathrm{O}$ concentrations in the system to $4.42 \%$ in runs with $3.0 \mathrm{~g} \mathrm{Na}{ }_{2} \mathrm{O} / 10 \mathrm{~g}$ solution. 

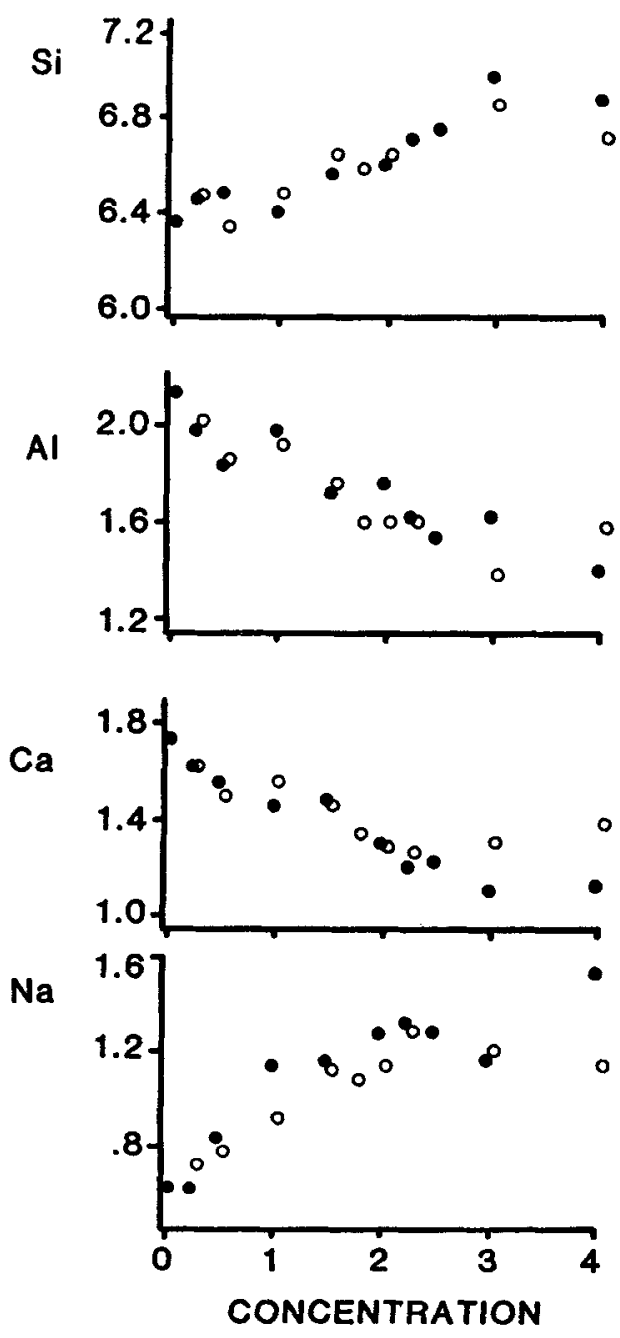

Figure 4. Variations in $\mathrm{Si}, \mathrm{Al}, \mathrm{Ca}$ and $\mathrm{Na}$ (as cations per 23 oxygen) for amphiboles crystallized in the pyrolite- $\mathrm{Na}_{2} \mathrm{CO}_{3}-\mathrm{H}_{2} \mathrm{O}$ system plotted against concentrations of $\mathrm{g} \mathrm{Na}_{2} \mathrm{O} / 10 \mathrm{~g} \mathrm{H}_{2} \mathrm{O}$ (closed circles) and $\mathrm{g} \mathrm{Na}_{2} \mathrm{O}+\mathrm{K}_{2} \mathrm{O} / 10 \mathrm{~g}$ solution $(\mathrm{K} / \mathrm{K}+\mathrm{Na}=0 \cdot 1)$ (open circles) (after McNeil and Edgar 1987).

Increasing amounts of amphibole formed at increasing bulk $\mathrm{Na}_{2} \mathrm{O}$ concentrations reduced the $\mathrm{H}_{2} \mathrm{O} / \mathrm{H}_{2} \mathrm{O}+\mathrm{CO}_{2}$ ratio in the fluids from 1.00 with solutions in which no $\mathrm{Na}_{2} \mathrm{O}$ was present to 0.91 for fluids in experiments with $3.0 \mathrm{~g} \mathrm{Na} \mathrm{Na}_{2} \mathrm{O} / 10 \mathrm{~g}$ solution.

Based on their X-ray intensity data (figure 3) mineral and fluid compositions, McNeil and Edgar (1987) proposed that the formation of amphibole was the result of a reaction

$$
\text { orthopyroxene + clinopyroxene }+ \text { spinel } \stackrel{\mathrm{Na}_{2} \mathrm{O}+\mathrm{H}_{2} \mathrm{O}}{\longrightarrow} \text { amphibole }+ \text { olivine. }
$$

This reaction is similar to that proposed by Olafsson and Eggler (1983) and Schneider and Eggler (1986) based on experiments with measured K-bearing fluids in which least 


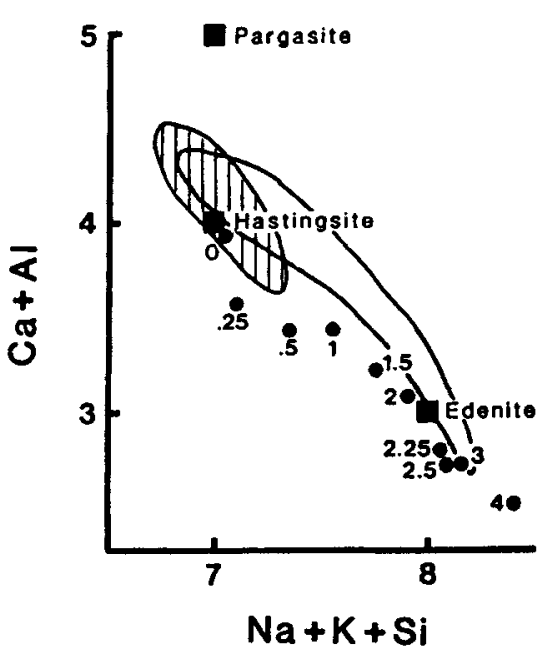

Figure 5. Plot of $\mathrm{Ca}+\mathrm{Al}$ vs $\mathrm{Na}+\mathrm{K}+\mathrm{Si}$ (as cations per 23 oxygen) for natural amphiboles from metasomatized mantle xenoliths. Ti-rich pargasites - vertically lined field, pargasitesenclosed open field. Closed circles represent amphiboles produced in the pyrolite- $\mathrm{Na}_{2} \mathrm{CO}_{3}$ $\mathrm{H}_{2} \mathrm{O}$ system at $20 \mathrm{~kb}, 950^{\circ} \mathrm{C}$ using concentrations as $\mathrm{g} \mathrm{Na}{ }_{2} \mathrm{O} / 10 \mathrm{~g}$ solution given after each data point. Closed squares represent end-member amphibole compositions (after McNeil and Edgar 1987).

square calculations suggested that clinopyroxene + orthopyroxene + spinel could be converted to $\mathrm{K}$-pargasite + olivine at about $20 \mathrm{~kb}$.

The applicability of these experiments to actual Na-dominant mantle metasomatism was demonstrated by comparing the compositions of amphiboles in the experiments with those of natural amphiboles formed under comparable depths. The decrease of $\mathrm{Ca}+\mathrm{Al}$ with increasing $\mathrm{Na}+\mathrm{K}+\mathrm{Si}$ in the experimental amphiboles is very similar to that of natural pargasite-edenite rather than to Ti-pargasites (figure 5), suggesting that the former may be produced by a process similar to that modelled by the experiments of McNeil and Edgar (1987). Similarly the experimental amphiboles correlate with natural pargasite-edenite rather than with Ti-rich pargasite on a plot of the $\mathrm{Mg} /(\mathrm{Mg}+\mathrm{Fe}$ ) ratio vs Si (figure 6). McNeil and Edgar (1987) consider that variations in natural amphiboles from $\mathrm{Ti}$ pargasite to pargasite-edenite may indicate a transition between precipitation from a residual liquid which is silicatedominant to one which is $\mathrm{H}_{2} \mathrm{O}$-dominant.

The presence of clinopyroxene in metasomatized mantle xenoliths containing pargasite-edenite suggests that natural metasomatic processes probably occur under concentrations of $\mathrm{Na}_{2} \mathrm{O}$ less than $1.5 \mathrm{~g} \mathrm{Na}_{2} \mathrm{O} / 10 \mathrm{~g}$ solution as modelled by the simplified experiments of McNeil and Edgar (1987). These experiments demonstrated that with increasing intensity of $\mathrm{Na}$-metasomatism, the model proportions of amphibole and their $\mathrm{Na}$-contents progressively increase. A maximum of about $43 \mathrm{wt} \%$ amphibole with greater than $5.5 \mathrm{wt} \% \mathrm{Na}_{2} \mathrm{O}$ can occur in model pyrolite under $\mathrm{Na}_{2} \mathrm{O}$ rich fluid conditions in which $\mathrm{H}_{2} \mathrm{O} / \mathrm{CO}_{2}$ is high. Such a hydrated pyrolite can contain $0.8 \mathrm{wt} \% \mathrm{H}_{2} \mathrm{O}$ and $1.7 \mathrm{wt} \% \mathrm{Na}_{2} \mathrm{O}$. In contrast, the maximum amount of calcic amphibole in mantle peridotite is about $15 \mathrm{wt} \%$ requiring $0.4 \mathrm{wt} \% \mathrm{H}_{2} \mathrm{O}$ (Eggler 1978; Wyllie 1978; Schneider and Eggler 1986).

Although the lowering of the pyrolite solidus in the system pyrolite- $\mathrm{Na}_{2} \mathrm{CO}_{3}-\mathrm{H}_{2} \mathrm{O}$ 


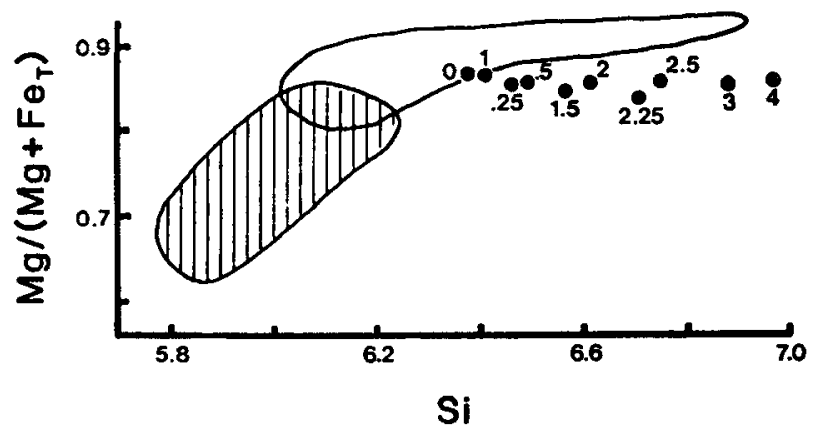

Figure 6. Relationship between $\mathrm{Mg} /\left(\mathrm{Mg}+\mathrm{Fe}_{\mathrm{T}}\right)$ vs $\mathrm{Si}$ (as cations per 23 oxygen) for natural amphiboles from metasomatized mantle xenoliths (see figure 5) and for amphiboles from the pyrolite- $\mathrm{Na}_{2} \mathrm{CO}_{3}-\mathrm{H}_{2} \mathrm{O}$ system at $20 \mathrm{~kb}, 950^{\circ} \mathrm{C}$ using various concentrations of $\mathrm{Na}_{2} \mathrm{O}$ (as $\mathrm{g} \mathrm{Na}_{2} \mathrm{O} / 10 \mathrm{~g}$ solution). Concentrations are shown after each data point (after McNeil and Edgar 1987).

at $950^{\circ} \mathrm{C}$ and $20 \mathrm{~kb}$ is less than that of the pyrolite $-\mathrm{K}_{2} \mathrm{CO}_{3}-\mathrm{H}_{2} \mathrm{O}$ system, it is still about $50^{\circ} \mathrm{C}$ lower than in the pyrolite- $\mathrm{H}_{2} \mathrm{O}$ system (Green 1973). Thus the addition of both these alkalies provides a mechanism of generating low temperature silicatedominant, alkali-rich melts which can subsequently metasomatize at shallower mantle levels.

\subsection{The pyrolite- $\mathrm{CaCO}_{3}$ system}

The experimental investigation of the pyrolite- $\mathrm{CaCO}_{3}$ system was undertaken to explain phenomena such as the partial replacement of orthopyroxene by aggregates of olivine and clinopyroxene grains in spinel harzburgite mantle xenoliths of the West Eifel alkaline volcanic province, West Germany. This suggests that some of the olivine-rich lherzolite and wehrlite of the region could be the end product of $\mathrm{Ca}$-dominated metasomatic processes acting on a lithospheric mantle of harzburgitic composition (Edgar et al 1989). As $\mathrm{CO}_{2}$ is an important volatile component in some highly alkaline volcanic provinces associated with continental rifting, a possible mechanism for enhancing the level of $\mathrm{Ca}$ could be a fluid flux containing significant $\mathrm{CaCO}_{3}$ (Bailey 1985). The system was kept dry mainly because of the absence of hydrous phases in many xenoliths of harzburgitic composition showing partial replacement of orthopyroxene. This suggests that the hypothetical Ca-enrichment process can be active in originally dry mantle material.

Results of experiments in the pyrolite $+10 \mathrm{wt} \% \mathrm{CaCO}_{3}$ system are presented in figure 7. A decarbonation reaction divides the subsolidus portion into a low temperature dolomite lherzolite field and a high temperature wehrlite $+\mathrm{CO}_{2}$ field. Between 25 and $28 \mathrm{~kb}$, the solidus shifts towards lower temperature, intersecting the decarbonation reaction (figure 7).

In the dolomite lherzolite field, run products consist of olivine, orthopyroxene, clinopyroxene, calcitic dolomite and spinel at low and garnet at high pressures.

In the wehrlite $+\mathrm{CO}_{2}$ field, orthopyroxene and dolomite are absent and the run products consist of olivine, clinopyroxene, spinel and $\mathrm{CO}_{2}$ vapour. Runs in the pyrolite $+18 \mathrm{wt} \% \mathrm{CaCO}_{3}$ system, have an excess of $\mathrm{Ca}$-rich carbonate $(\geqslant 83 \mathrm{~mol} \%$ 


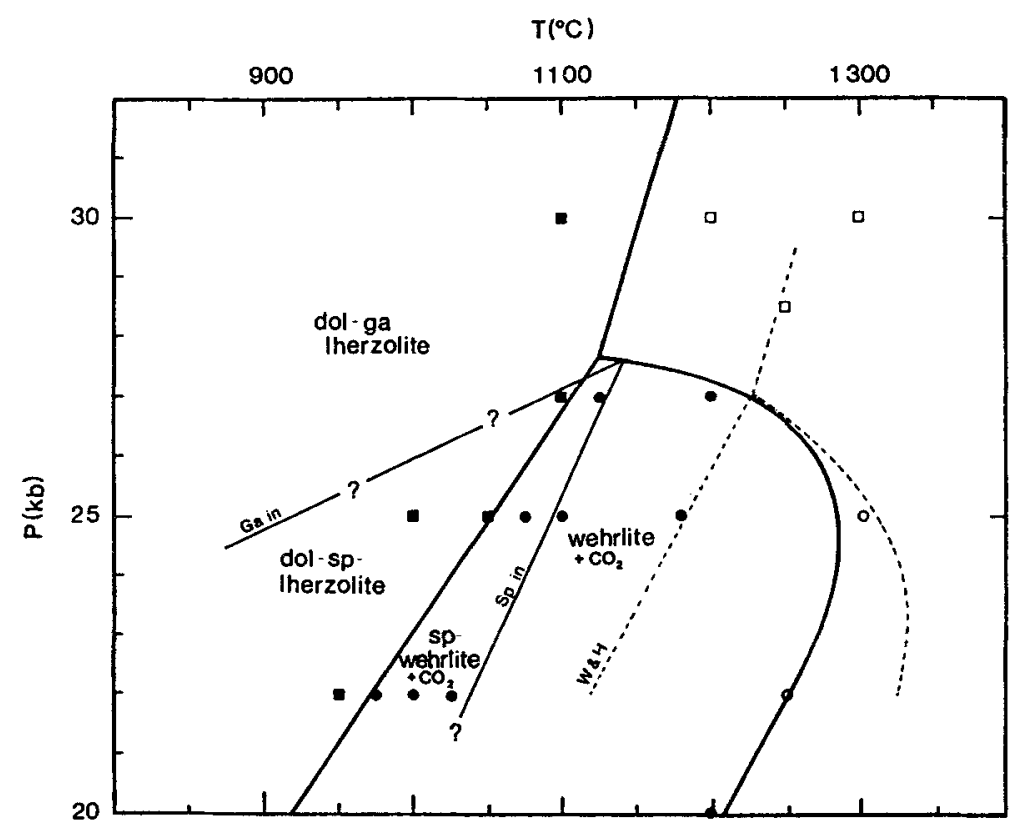

Figure 7. Phase relationships for the system pyrolite-10wt $\% \mathrm{CaCO}_{3}$. Heavy lines indicate the location of the decarbonation reaction and of the solidus. Dashed lines show the same relations in the simple system $\mathrm{CaO}-\mathrm{MgO}-\mathrm{SiO}_{2}-\mathrm{CO}_{2}$ based on data of Wyllie and Huang (1976) and Wyllie et al (1983). Filled and open symbols represent subsolidus and suprasolidus conditions respectively. Squares and circles indicate the presence or absence of orthopyroxene respectively $(\mathrm{dol}=$ dolomite; $\mathrm{sp}=$ spinel; ga $=$ garnet; $\mathrm{W} \& \mathrm{H}=\mathrm{Wyllie}$ and Huang 1976).

$\left.\mathrm{CaCO}_{3}\right)$ in the wehrlite $+\mathrm{CO}_{2}$ field in accordance with calcite being stable in wehrlitic compositions in this pressure range (Edgar et al 1988).

The nature of the decarbonation reaction was defined using mineral compositions and proportions calculated by least-squares mass balance for two adjacent runs, close to the determined reaction. The proposed reaction (table 1 ) is almost similar to the reaction, orthopyroxene + dolomite $\rightarrow$ clinopyroxene + olivine $+\mathrm{CO}_{2}$, determined in peridotitic systems with $\mathrm{CO}_{2}$ added (Wyllie and Huang 1976; Eggler 1978; Brey et al 1983). Also a small proportion of spinel reacting with orthopyroxene increases the abundance.of olivine and of the Ts component in the clinopyroxene. This is suggested by a systematic decrease in the abundance of spinel on the high temperature side of the reaction. Moreover, as $\mathrm{Al}$ enters more easily than $\mathrm{Cr}$ in clinopyroxene relative to spinel, the latter is systematically more chromiferous in nature in the wehrlite $+\mathrm{CO}_{2}$ field.

Of petrological importance is the fact that the decarbonation reaction in the pyrolite $+\mathrm{CaCO}_{3}$ system is about 100 to $150^{\circ} \mathrm{C}$ lower than in the simple system modelling dry peridotitic assemblages with $\mathrm{CO}_{2}$ added (Eggler 1978; Wyllie et al 1983; see figure 7).

Using back-scattered imaging, suprasolidus conditions at $30 \mathrm{~kb}$ were recognized in the form of interstitial material. The material is not glass but an aggregate of extremely fine grains believed to have quenched from a very low viscosity melt. The exact nature of the melt could not be characterized. However, qualitative probe 
Table 1. Proposed decarbonation reaction (in simplified form) in the system pyrolite $+10 \mathrm{wt}^{\%} \mathrm{CaCO}_{3}$.

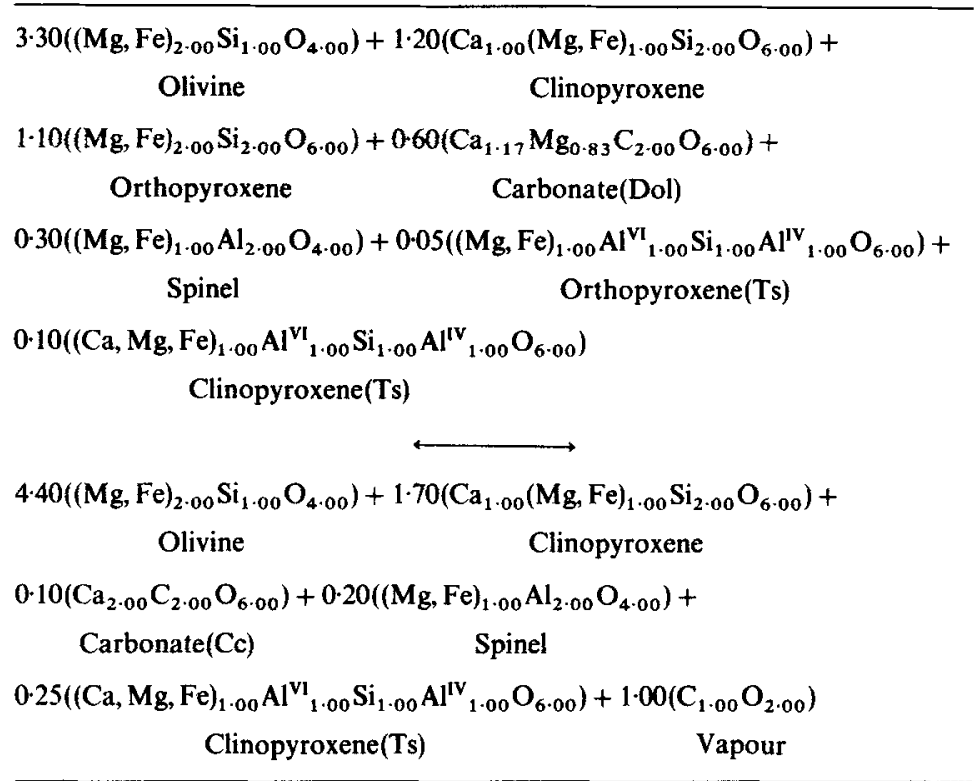

analyses of the interstitial material for a run at $1200^{\circ} \mathrm{C}$ and $30 \mathrm{~kb}$ yield low totals of about $60 \%$ and low silica content $(<4 \%)$, with $\mathrm{CaO}$ and $\mathrm{MgO}$ as the main oxides. This suggests a $\mathrm{CO}_{2}$-rich dolomitic melt. Therefore the solidus temperature and the carbonatitic nature of the melt at low degrees of partial melting is concordant with Wendlandt and Mysen's (1980) results on dry natural peridotite with $\mathrm{CO}_{2}$ added.

The sodium content of clinopyroxene decreases significantly at the solidus at $30 \mathrm{~kb}$. Because there is no other Na-bearing minerals and the clinopyroxene abundances do not increase, $\mathrm{Na}$ is probably partitioned quantitatively in the $\mathrm{CO}_{2}$-rich melt. This is in accordance with the experimental results of Wallace and Green (1988) on the phase relationships of a carbonate and amphibole-bearing lherzolite assemblage from which the first satisfying and precise composition of high pressure primary carbonatite magma was determined. Wallace and Green (1988) noted that the melt is strongly enriched in $\mathrm{Na}_{2} \mathrm{CO}_{3}$ and that the high pressure solidus is defined by the breakdown of dolomite and of the jadeite component of the clinopyroxene to produce an aluminous phase plus melt.

In order to relate these experimental results to Ca-dominant metasomatism of the West Eifel xenoliths, a geotherm shown in figure 8 is applied to the phase relations given in figure 7. This qualitative geotherm is believed to represent a minimum based on geothermometry calculations and geophysical modelling reported by Seck and Wedepohl (1983) and Fuchs and Wedepohl (1983) for the Rhenish Massif. With such a high geotherm, the solidus is crossed in a dry lherzolitic mantle at approximately $100 \mathrm{~km}$ depth and therefore a small fraction of carbonatitic melt is formed if $\mathrm{CO}_{2}$ is supplied or is already available as a carbonate phase (figure 8). Hunter and McKenzie (1989) have shown experimentally that, even at small degrees of partial melting, such a melt will form an interconnected network. Therefore, as predicted by McKenzie (1984, $1985)$, very small fractions $(<1 \%$ ) of such a low viscosity melt can efficiently segregate 


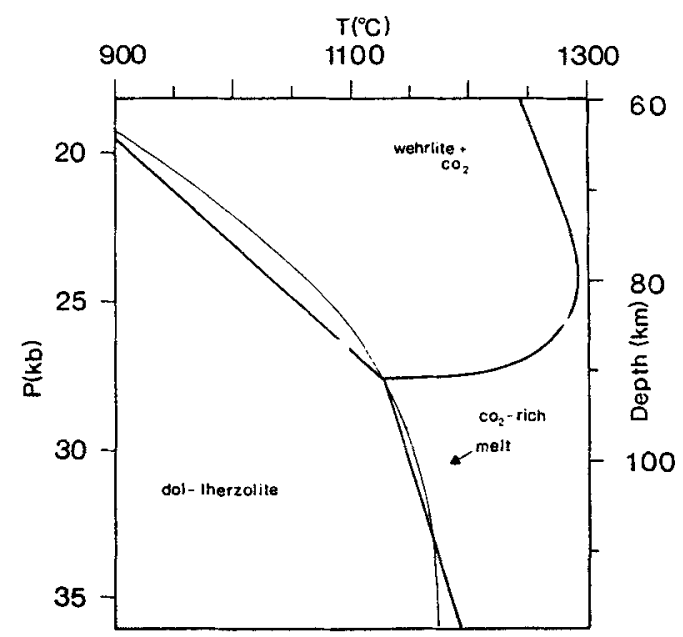

Figure 8. Tentative geotherm, believed to be applicable to the upper mantle in the West Eifel area, applied to the pressure-temperature relations shown in figure 7. For details refer to text (abbreviations as in figure 7).

from their mantle source. However because the geotherm in the West Eifel is such that the melt crosses its solidus in the wehrlite $+\mathrm{CO}_{2}$ field (figure 8), it probably becomes highly reactive relative to a dry harzburgitic mantle at a pressure of $25 \mathrm{~kb}$ or less, the dolomitic component of the melt reacting with orthopyroxene to form olivine, clinopyroxene and $\mathrm{CO}_{2}$ vapor. If the melt flux is sufficient, an olivine-rich wehrlite can eventually form. As long as the system is kept dry, the possible addition of $\mathrm{Na}$ is limited by its solubility in clinopyroxene. Therefore, we are in agreement with Green and Wallace (1988) and Wallace and Green (1988) that high pressure primary carbonatitic melts are very effective metasomatic agents. In an amphibole-bearing lherzolite the transformation to wehrlitic compositions is restricted to pressures less than $21 \mathrm{~kb}$ (Green and Wallace 1988). In contrast our results suggest that a dry harzburgitic mantle could probably be subjected to this type of metasomatism up to a depth corresponding to $25 \mathrm{~kb}$ provided, conditions as that of the West Eifel geotherm are reached.

\subsection{Melting of a model metasomatized mantle source}

Lloyd et al (1985) determined the compositions of liquids produced from partial melting of a model alkali clinopyroxenite composition which they considered representative of the metasomatized xenoliths in the Katwe-Kikorongo and Bunyaruguru volcanic fields of South-West Uganda. This model xenolith contained the metasomatic mineral assemblage of clinopyroxene + phlogopite + magnetite + sphene + apatite (table 2); diagnostic of $\mathrm{Ca}$ and $\mathrm{K}$ but a little $\mathrm{Na}$ metasomatism under mantle conditions. The objectives of the experiments were to determine whether such a model-metasomatized mantle composition could partially melt to produce a liquid whose composition corresponds to that of the principal host lava (katungite) of this area, as inferred from the near-liquidus experiments of Arima and Edgar (1983).

Figure 9 shows the compositions of liquids formed between $1175^{\circ} \mathrm{C}$ and $1200^{\circ} \mathrm{C}$ at $30 \mathrm{~kb}$ from partial melts of $20 \mathrm{wt} \%$ to complete melting, and the incoming minerals 
Table 2. Modal and chemical composition of model alkali clinopyroxenite used in Lloyd et al (1985) experiments. Compositions of 26 katungites from South-West Uganda and composition of glass from $25 \%$ partial melting of average composition of model alkali clinopyroxenite (from Lloyd et al 1985).

\begin{tabular}{lccccc}
\hline Volume \%) & $\mathrm{A}$ & $(\mathrm{wt} \%)$ & $\mathrm{B}$ & $\mathrm{C}$ & $\mathrm{D}$ \\
\hline Clinopyroxene & 52 & $\mathrm{SiO}_{2}$ & 40.20 & 39.9 & 37.1 \\
Phlogopite & 35 & $\mathrm{TiO}_{2}$ & 4.92 & 5.28 & 5.55 \\
Apatite & 2 & $\mathrm{Al}_{2} \mathrm{O}_{3}$ & 7.27 & 7.84 & 6.78 \\
Sphene & 4 & $\mathrm{Fe}_{2} \mathrm{O}_{3}$ & 6.69 & 6.81 & - \\
Magnetite & 6.5 & $\mathrm{FeO}$ & 7.12 & 5.38 & 11.9 \\
Jadeite & 0.5 & $\mathrm{MnO}$ & 0.09 & 0.21 & 0.18 \\
& & $\mathrm{MgO}$ & 12.60 & 10.15 & 10.1 \\
& & $\mathrm{CaO}$ & 12.21 & 12.35 & 12.4 \\
& & $\mathrm{Na}_{2} \mathrm{O}$ & 1.21 & 1.95 & 1.56 \\
& & $\mathrm{~K}_{2} \mathrm{O}$ & 4.18 & 4.96 & 4.06 \\
& & $\mathrm{H}_{2} \mathrm{O}^{+}$ & 1.49 & 2.27 & - \\
& & $\mathrm{CO}_{2}$ & 0.98 & 0.98 & - \\
& & $\mathrm{P}_{2} \mathrm{O}_{5}$ & 0.70 & 0.76 & 1.41 \\
& & $\mathrm{Total}^{2}$ & 99.66 & 98.84 & 91.04 \\
\hline
\end{tabular}

A-modal analysis of starting material in model alkali clinopyroxenite.

B-chemical analysis of model composition A.

C-average of 26 katungites from South-West Uganda.

D-composition of liquid from $25 \%$ partial melting of compositions $\mathrm{A}$ and $\mathrm{B}$ at $30 \mathrm{~kb}$.

with decreasing temperature. The correspondence between the compositions of glass determined by microprobe analyses with that obtained by least-squares mass balance calculation is excellent (figure 9). The interpolated composition of glass at $25 \%$ partial melting (table 2) corresponds very closely to the average of 26 katungites (table 2) suggesting that metasomatized alkali clinopyroxenite was the source for such a lava.

Partial melting of the model mantle xenolith at $20 \mathrm{~kb}$ could not unequivocally show that partial melting at this pressure produce liquids comparable to the natural lavas found in South-West Uganda. However, based on theoretical considerations, Lloyd et al (1985) do not consider that any degree of partial melting is likely to produce such magmas.

The greater amount of heat necessitated by the high degrees of partial melting inferred from these experiments may be provided by the $\mathrm{K}_{2} \mathrm{O}$ content of the model xenolith used by Lloyd et al (1985). As this is 150-200 times greater than that of model pyrolite (Ringwood 1975 ), the amount of ${ }^{40} \mathrm{~K}$ (and probably $U$, Th) necessary to supply this additional heat is available.

\section{Conclusions and future studies}

In this paper we have attempted to show how experimental petrology can be used to model the major types of mantle metasomatism involving $\mathrm{K}, \mathrm{Na}$ and $\mathrm{Ca}$ which produce phlogopite, amphibole and clinopyroxene as diagnostic mineral phases. 


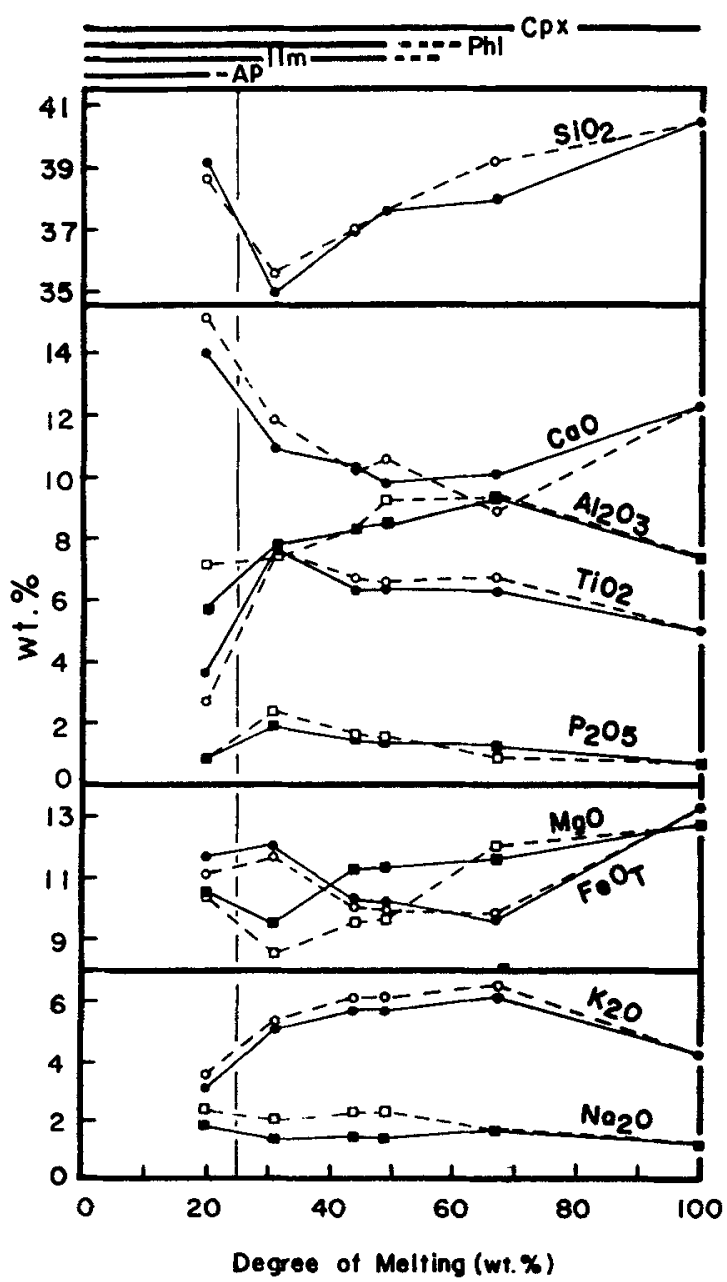

Figure 9. Determined and calculated melt compositions from various degrees of partial melting of alkali clinopyroxenite xenolith (table 1) at $30 \mathrm{~kb}$. Experimentally determined crystallization sequence given at the top of figure. Solid symbols represent determined glass compositions, open symbols represent calculated compositions (see text). Vertical dashed line is interpolated composition of melt at $25 \%$ partial melting. Other abbreviations as in figure 1 and IIm-ilmenite, Ap-apatite (after Lloyd et al 1985).

These experiments constrain possible $P, T$ conditions under which these minerals commonly occur in metasomatized mantle-derived xenoliths in South-West Uganda and in the West Eifel region of Germany.

Although these experiments are very simplified relative to the natural metasomatic processes, they can be used to model what appears to be stages of predominance of one type of metasomatism relative to another. Such stages appear to be related to depth in the mantle and availability of a particular fluid species. Studies are in progress to develop an evolutionary metasomatic model for $\mathrm{K}, \mathrm{Na}$ and $\mathrm{Ca}$ metasomatism. 


\section{Acknowledgements}

The authors acknowledge useful discussions with Dr. F E Lloyd who shared her knowledge and a vast collection of specimens of the Eifel and Uganda regions. Financial support was provided by the operating and major installation grants from the Natural Sciences and Engineering Research Council of Canada to ADE. Funding from NATO as a Collaborative Research Grant is also acknowledged. Y T thanks the FCAR for pre-doctoral scholarship. This paper is dedicated to the late Sir C V Raman, on the occasion of his birth centenary.

\section{References}

Arima M and Edgar A D 1983 High pressure experimental studies on a katungite and their bearing on the genesis of some potassium-rich magmas of the west branch of the African rift; J. Petrol. 74 166-187

Bailey D K 1982 Mantle metasomatism-continued chemical change within the earth; Nature (London) $296525-580$

Bailey D K 1985 Fluids, melts, flowage and styles of eruption in alkaline ultramafic magmatism; Trans. Geol. Soc. S. Afr. 88 449-457

Bailey D K 1987 Mantle metasomatism-perspective and prospect. In Alkaline igneous rocks (ed) J G Fitton and B G J Upton, (Geological Society Special Publication) 30 1-13

Boyd F R and England J L 1960 Apparatus for phase equilibrium measurements at pressures up to $50 \mathrm{~kb}$ and temperatures to $1750^{\circ} \mathrm{C} ; J$. Geophys. Res. $65741-748$

Brey G, Brice W R, Ellis D J, Green D H, Harris K L and Ryabchikov I D 1983 Pyroxene-carbonate reactions in the upper mantle; Earth Planet. Sci. Lett. 62 63-74

Dawson L B 1984 Contrasting types of upper mantle metasomatism? In Kimberlites II. The mantle and crust-mantle relationships (ed) J Kornprobst (Amsterdam: Elsevier) pp. 289-294

Edgar A D and Arima M 1984 Experimental studies on K-metasomatism of a model pyrolite mantle and their bearing on the genesis of ultrapotassic magmas; Proc. 27th Int. Geol. Congr. Petrol. (Igneous and Metamorphic Rocks) 9 509-541

Edgar A D, Arima M, Baldwin D K, Bell D R, Shee S R, Skinner M W and Walker E C 1988 Highpressure-high-temperature melting experiments on a $\mathrm{SiO}_{2}$-poor aphanitic kimberlite from the Wesselton mine, Kimberley, South Africa; Am. Mineral. 73 524-533

Edgar A D, Lloyd F E, Forsyth D M and Barnett R L 1989 Origin of glass in upper mantle xenoliths from the quaternary volcanics S E of Gess, West Eifel, Germany, (in prep.)

Eggler D H 1978 The effect of $\mathrm{CO}_{2}$ upon partial melting of peridotite in the system $\mathrm{Na}_{2} \mathrm{O}-\mathrm{CaO}-\mathrm{Al}_{2} \mathrm{O}_{3}$ $\mathrm{MgO}-\mathrm{SiO}_{2}-\mathrm{CO}_{2}$ to $35 \mathrm{~kb}$, with an analysis of melting in a peridotite- $\mathrm{H}_{2} \mathrm{O}-\mathrm{CO}_{2}$ system; $\mathrm{Am}$. J. Sci. 278 305-343

Eggler D H 1987 Solubility of major and trace elements in mantle metasomatic fluids: experimental constraints. In Mantle Metasomatism (ed) M A Menzies and C J Hawkesworth (Academic Press London) pp. 21-41

Fuchs K and Wedepohl K H 1983 Relation of geophysical and petrological models of upper mantle structure of the Rhenish Massif. In Plateau uplift: The rhenish shield-A case history (eds) $\mathrm{K}$ Fuchs, K von Gehlen, H Malzer, H Murawski and A Semmel (Springer Verlag) pp. 352-363

Green D H 1973 Experimental melting studies on a model upper mantle composition at high pressure under water saturated and water-undersaturated conditions; Earth Planet. Sci. Lett. $1937-53$

Green D H and Wallace M E 1988 Mantle metasomatism by ephemeral carbonatite melts; Nature (London) $336459-462$

Harte B and Gurney J J 1975 Ore mineral and phlogopite mineralization within ultramafic nodules from the Matsoku kimberlite pipe, Lesotho; Carnegie Inst. Washington, Yearb. 74 528-536

Hunter R H and McKenzie D 1989 The equilibrium geometry of carbonate melts in rocks of mantle composition; Earth Planet. Sci. Lett. 92 347-356

Lloyd F E, Arima M and Edgar A D 1985 Partial melting of a phlogopite clinopyroxenite nodule from South-West Uganda: An experimental study bearing on the origin of highly potassic, continental rift volcanics; Contrib. Mineral. Petrol. 91 321-329 
Lloyd F E and Bailey D K 1975 Light element metasomatism of the continental mantle: the evidence and the consequences; Phys. Chem. Earth 9 389-416

McKenzie D 1984 The generation and compaction of partially molten rock; J. Petrol. 25 713-765

McKenzie D 1985 The extraction of magma from the crust and mantle; Earth Planet. Sci. Lett. 74 81-91

McNeil A M and Edgar A D 1987 Sodium-rich metasomatism in the upper mantle: Implications of experiments on the pyrolite- $\mathrm{Na}_{2} \mathrm{O}$-rich fluid system at $950^{\circ} \mathrm{C}, 20 \mathrm{kbar}$; Geochim. Cosmochim. Acta 51 2285-2294

Menzies M A and Hawkesworth C J 1987 Mantle Metasomatism; (Academic Press London) p. 472

Olafsson M and Eggler D H 1983 Phase relations of amphibole, amphibole-carbonate, and phlogopitecarbonate peridotite: Petrologic constraints on the asthenosphere; Earth Planet. Sci. Lett. 64 305-315

Ringwood A E 1975 Composition and Petrology of the Earth's Mantle (McGraw-Hill, New York) p. 618

Schneider M E and Eggler D H 1986 Fluids in equilibrium with peridotite minerals: Implications for mantle metasomatism; Geochim. Cosmochim. Acta 50 711-724

Seck H A and Wedepohl K H 1983 Mantle xenoliths in the Rhenish Massif and the Northern Hessian Depression. In Plateau uplift: The rhenish shield-A case history (eds) H Fuchs, $\mathrm{K}$ von Gehlen, H Malzer, H Murawski and A Semmel (Springer Verlag) pp. 343-351

Spera F J 1987 Dynamics of translithospheric migration of metasomatic fluid and alkaline magma. In Mantle Metasomatism (ed) M A Menzies and C J Hawkesworth. (Academic Press London) pp. 1-20

Takahashi E and Kushiro I 1983 Melting of a dry peridotite at high pressures and basalt magma genesis; Am. Mineral. 68 859-879

Wallace M E and Green D H 1988 An experimental determination of primary carbonatite magma composition; Nature (London) 335 343-346

Wendlandt R F and Mysen B O 1980 Melting phase relations of natural peridotite $+\mathrm{CO}_{2}$ as a function of degree of partial melting at 15 and $30 \mathrm{kbar}$; Am. Mineral. $6537-44$

Wyllie P J 1978 Mantle fluid compositions buffered in peridotite- $\mathrm{H}_{2} \mathrm{O}-\mathrm{CO}_{2}$ by carbonates, amphibole and phlogopite; J. Geol. 86 687-713

Wyllie $\mathrm{P} \mathrm{J}$ and Huang W-L 1976 Carbonation and melting reactions in the system $\mathrm{CaO}-\mathrm{MgO}-\mathrm{SiO}_{2} \mathrm{CO}_{2}$ at mantle pressures with geophysical and petrological applications; Contrib. Mineral. and Petrol. 54 79-107

Wyllie P J, Huang W-L, Otto J and Byrnes A P 1983 Carbonation of peridotites and decarbonation of siliceous dolomites represented in the system $\mathrm{CaO}-\mathrm{MgO}-\mathrm{SiO}_{2}-\mathrm{CO}_{2}$ to $30 \mathrm{kbar}$; Tectonophysics 100 359-388 